\title{
ОХРАНА ОБЩЕСТВЕННОГО ПОРЯДКА И ОБЕСПЕЧЕНИЯ ОБЩЕСТВЕННОЙ БЕЗОПАСНОСТИ КАК ОСНОВНЫЕ НАПРАВЛЕНИЯ ДЕЯТЕЛЬНОСТИ ПОЛИЦИИ: ПРОБЛЕМЫ ПРАВОВОГО РЕГУЛИРОВАНИЯ
}

\author{
Т. М. Занина \\ Воронежский институт МВД России \\ О. А. Федотова \\ Центральный фбилиал Российского государственного \\ университета правосудия \\ Поступила в редакцию 26 октября 2020 г.
}

\begin{abstract}
Аннотация: статья посвящена вопросам норлативного обеспечения охраны общественного порядка и общественной безопасности в деятельности полииии. Приводится перечень законодательства, регулирующего отношения в данной собере. Дается также анализ толкованию определений "общественный порядок", "общественная безопасность", их особенностей, отличающих их от других категорий. Рассматриваются различные мнения ученьх, занилающихся исследованиел этой телатики. Отражаются проблель норлативно-правового регулирования и предлагаются меры, направленные на их устранение.

Ключевые слова: общественный порядок, общественная безопасность, нормативное правовое регулирование, правоохранительные органь, полииия, патрульно-постовая служба полищии.
\end{abstract}

Abstract: this article is devoted to the issues of normative regulation of the protection of public order and ensuring public safety in the process of police activity. A detailed list of legislation governing relations in this area is provided. It also provides a detailed analysis of the interpretation of the definitions "public order", "public safety", their features that distinguish them from other categories. The content addresses the various opinions of scholars doing research in the field. The article reflects the problems of legal regulation and suggests measures aimed at their elimination.

Key words: public order, public safety, legal regulation, law enforcement, police, police patrol service.

К числу важнейших современных задач относятся такие аспекты, как охрана общественного порядка и обеспечение общественной безопасности. В указанном направлении свою деятельность осуществляют большое количество субъектов.

Основной спектр функций в вопросах регулирования общественного порядка и обеспечения общественной безопасности возложен на правоохранительные органы, в первую очередь на полицию. Полиция и другие государственные органы, а также организации осуществляют непрерывную работу по устранению правонарушений, используя не только

(C) Занина Т. М., Федотова О. А., 2021 
правовые средства, но и средства морального воздействия, такие как принуждение и убеждение.

Согласно действующему Кодексу Российской Федерации об административных правонарушениях (далее - КоАП РФ) административная ответственность по рассматриваемому виду правонарушений закреплена в главе 20. Однако согласно проекту нового КоАП РФ таким правонарушениям посвящена глава 13. Исходя из анализа предлагаемых изменений, следует отметить, что перечень административных правонарушений, посягающих на общественный порядок и общественную безопасность, расширен, добавлены новые виды правонарушений, а также ужесточена ответственность и санкции.

Следует отметить, что каждое происходящее социально-экономическое или политическое изменение в государстве ставит перед полицией новые цели и задачи в сфрере охраны общественного порядка и обеспечения общественной безопасности, так как именно полиция, согласно действующему законодательству, является ключевым субъектом такой деятельности.

В связи с этим полицейская деятельность нуждается в постоянной модернизации, в рамках которой должно на непрерывной основе осуществляться техническое и кадровое переоснащение органов внутренних дел, укрепление морально-психологического климата в служебных коллективах, подготовка и отбор квалифицированных и честных сотрудников. Всё это будет способствовать профессиональному и нравственному росту.

Существующие противоправные посягательства на общественный порядок и безопасность должны поддаваться противодействию благодаря комплексам мер превентивного, пресекательного характера. Полиция в этом случае применяет комплекс мер, в который входят принуждение, обеспечение производства по делам об административных правонарушениях, административные наказания.

Вышеуказанные аспекты должны обеспечиваться проведением систематической работы по совершенствованию нормативно-правовой базы деятельности полиции, регулирующей охрану общественного порядка и обеспечение общественной безопасности.

Общественный порядок и общественная безопасность являются фрундаментальными элементами безопасности граждан, общества и государства. Исходя из сложившейся обстановки в Российской Федерации, нельзя признать их состояние удовлетворительным. Это объясняется следующими причинами:

1) рост количества административных правонарушений и преступлений в сфрере общественного порядка и безопасности граждан;

2) латентность такого вида правонарушений и преступлений;

3) государственные реформирования, повлекшие за собой увеличение числа лиц без определенного места жительства, совершивших правонарушения, что усиливает угрозу безопасности общества и государства.

Остановимся более подробно на толковании понятий «общественный порядок» и «общественная безопасность». 
Категории «общественный порядок» и «общественная безопасность» применяют как две части одного целого. Во всех нормативных актах эти два понятия не разделяют, их используют всегда вместе. Для более точного понимания сущности данных правовых категорий рассмотрим каждую более подробно.

В законодательстве не закреплен термин «общественный порядок». Многие ученые-правоведы, занимаясь изучением вышеуказанной темы, давали авторское толкование термину. Так, И. И. Веремеенко утверждал, что общественный порядок - это «система общественных отношений, возникающих и развивающихся в общественных местах в процессе общения людей, правовое и иное социальное регулирование которых обеспечивает их личную и общественную безопасность и, тем самым, обстановку спокойствия, согласованности и ритмичности общественной жизни» ${ }^{1}$.

В. В. Лазарев данное понятие понимал как «...свойство системы общественных отношений, состоящее в упорядоченности социальных связей, которая ведет к согласованности и ритмичности общественной жизни, беспрепятственному осуществлению участниками общественных отношений своих прав и обязанностей и защищенности их обоснованных интересов, общественному и личному спокойствию» ${ }^{2}$.

А. Г. Коротких справедливо указывает на многогранный характер исследуемой категории, обусловленный такими признаками, как: «специфичность системы общественных отношений; устанавливается и санкционируется государством посредством применения социальных норм; направлен на обеспечение общественного спокойствия и нормального функционирования всех сфер жизнедеятельности; обусловлен общественным местом возникновения» ${ }^{3}$.

Представляется целесообразным предложить авторское толкование «общественного порядка» - общественные отношения, возникающие и развивающиеся в условиях отсутствия негативных фракторов, которые могут внести любые нарушения в привычную жизнедеятельность граждан, их развитие.

Нормативное закрепление понятия «общественная безопасность» дано в Концепции общественной безопасности Российской Федерации принятой в 2013 г. Так, общественная безопасность есть не что иное, как «состояние защищенности человека и гражданина, материальных и духовных ценностей общества от преступных и иных противоправных по-

${ }^{1}$ Верелеенко И. И. Механизм административно-правового регулирования в сфрере охраны общественного порядка : учебник. М., 1981. С. 21.

${ }^{2}$ Лазарев В. В., Попов Л. Л., Розин Л. М. Правовые основы ООП : учеб. пособие. М., 1987. С. 9.

${ }^{3}$ Коротких А. Г. К дискуссии о понятии «общественный порядок» : проблемы применения в административном законодательстве // Вестник Воронеж. гос. унта. Серия: Право. 2016. № 2 (25). С. 168.

${ }^{4}$ Концепция общественной безопасности в Российской Федерации : утв. Президентом РФ 14 ноября 2013 г. № Пр-2685. Доступ из справ.-правовой системы «КонсультантПлюс». 
сягательств, социальных и межнациональных конфликтов, а также от чрезвычайных ситуаций природного и техногенного характера». Концепция является фрундаментальным документом, который определяет государственную политику в данной сфрере. В ней содержится перечень основных продилактических мер, а также приводится перечень методов и способов, направленных на совершенствование нормативной правовой базы в направлении обеспечения общественной безопасности. Важной особенностью является создание государственных систем мониторинга за состоянием общественной безопасности, разработка и последующее внедрение целевых программ.

Общественную безопасность можно определить в узком и широком смысле. В широком смысле общественная безопасность затрагивает различные сфреры общественных отношений, включая также общественный порядок. Например, А. Г. Коротких определяет общественную безопасность как «состояние защищенности личности и общества от совокупности угроз противоправного, техногенного, природного, космического, экологического и иного характера различными по своему характеру и значимости мерами» 5 .

Кроме того, и узкое понимание общественной безопасности включает сфреру общественного порядка при проведении конкретных работ.

Под правовой основой охраны общественного порядка (далее - ООП) и обеспечения общественной безопасности (далее - ООБ) подразумевается совокупность нормативных правовых актов международного и внутригосударственного уровня, регулирующих деятельность сотрудников в указанной сфрере.

ООП и ООБ являются многоаспектными категориями. На основании п. «б» ст. 72 Конституции РФ «обеспечение законности, правопорядка, общественной безопасности» ${ }^{6}$ относится к совместному ведению Российской Федерации и ее субъектов.

Особое внимание в рассматриваемом направлении следует уделить Федеральному закону от 7 февраля 2011 г. № 3-ФЗ «О полиции» ${ }^{7}$. В п. 1 ст. 1 «Назначение полиции» указывается, что полиция предназначена в том числе и для ООП, и ООБ. Осуществляя реализацию данных направлений, полиция как одна из составляющих системы органов внутренних дел наделена определенной категорией прав и обязанностей, которые также отражены в Законе «О полиции».

Как отмечалось выше, категории ООП и ООБ многогранны. В связи с этим в различных отраслях права им уделяется большое внимание. Так, в уголовном законодательстве им посвящен раздел IX «Преступления против общественной безопасности и общественного порядка». Если

${ }^{5}$ Коротких А. Г. О сути и значении понятий «общественный порядок» и «общественная безопасность» // Вестник Воронеж. ин-та МВД России. 2011. № 3. С. 42.

${ }^{6}$ Конституция Российской Федерации : принята всенародным голосованием 12 декабря 1993 г. URL: http://www.pravo.gov.ru (дата обращения: 10.09.2020).

${ }^{7}$ О полиции : федер. закон от 7 фревраля 2011 г. № 3-ФЗ (в ред. от 06.02.2020). Доступ из справ.-правовой системы «КонсультантПлюс». 
рассматривать административное законодательство, которое представляет большой интерес для исследования, то в КоАП РФ указанным категориям посвящена глава XX, где содержатся нормы, предусматривающие административную ответственность за совершение противоправных деяний, нарушающих ООП и ООБ.

Для более точного уяснения норм административного законодательства в сфрере общественного порядка и общественной безопасности следует учитывать иные нормативные правовые акты, среди которых федеральные законы:

от 6 марта 2006 г. № 35-ФЗ (в ред. от 18.03.2020) «О противодействии терроризму»; от 25 июля 2002 г. № 114-ФЗ (в ред. от 31.07.2020) «О противодействии экстремистской деятельности»; от 26 сентября 1997 г. № 125Ф3 (в ред. от 02.12.2019) «О свободе совести и о религиозных объединениях» ${ }^{8}$.

В развитие положений фредерального законодательства особенности правового статуса органов внутренних дел при осуществлении ООП и ООБ установлены в отдельных ведомственных нормативно-правовых актах, таких как приказы МВД России:

от 29 января 2008 г. № 80 (в ред. от 12.02.2015) «Вопросы организации деятельности строевых подразделений патрульно-постовой службы полиции»; от 30 августа 2017 г. № 685 «О должностных лицах системы Министерства внутренних дел Российской Федерации, уполномоченных составлять протоколы об административных правонарушениях и осуществлять административное задержание» ${ }^{9}$.

Особое значение для Российской Федерации имеют вопросы правового регулирования сореры проведения массовых мероприятий, где ООП и ООБ являются приоритетным направлением деятельности правоох- ранительных органов. В свою очередь, деятельность полиции в данной 이 copepe также регламентирована нормативно-правовыми актами. $\mathrm{K}$ ним Z следует отнести Федеральный закон от 19 июля 2004 г. № 54-Ф3 (в ред. $\bar{\sim}$ от 11.10.2018) «О собраниях, митингах, демонстрациях, шествиях и пикетированиях» ${ }^{10}$.

В Российской Федерации деятельность по обеспечению указанных правовых категорий отводится сотрудникам патрульно-постовой службы полиции.

Патрульный полицейский выполняет основную работу по ООП и ООБ, особенно на объектах транспортной инфраструктуры. Важно отметить, что такая работа выполняется при взаимодействии с гражданами, например, если возникает какая-либо чрезвычайная ситуация либо совершается административное правонарушение или преступление. В этом случае сотрудник патрульно-постовой службы должен оказать по-

\footnotetext{
8 Доступ из справ.-правовой системы «КонсультантПлюс».

9 Доступ из справ.-правовой системы «КонсультантПлюс».

10 Доступ из справ.-правовой системы «КонсультантПлюс».
} 
мощь или содействие в разрешении возникшей ситуации различного характера.

Термин «патрульно-постовая служба полиции» (далее - ППСП) используется в теории и практике в двух значениях.

Во-первых, ППСП представляет собой вид деятельности, которую осуществляют специальные наряды полиции в рамках ООП и борьбе с преступностью, в форменной одежде на постах и маршрутах патрулирования.

Во-вторых, ППСП определяется как система аппаратов, частей и подразделений, которые осуществляют деятельность по ООП и ООБ.

Таким образом, ППСП является структурным подразделением в составе МВД России, деятельность которого направлена на ООП и ООБ на улицах, площадях, в парках, на транспортных магистралях, вокзалах, пристанях, в аэропортах и других общественных местах.

Данный вид деятельности имеет свою специфику. Это обосновывается тем, что руководитель органов внутренних дел и командир строевого подразделения ППСП на постоянной основе должен проводить комплекс мероприятий, который заключается в организации расстановки и использовании сил и средств, направленных на достижение наиболее эфрфективных ООП и ООБ.

К числу таких мероприятий относятся:

1. Определение районов и участков местности, где есть необходимость расстановки нарядов полищии.

2. Определение обязательного времени расстановки личного состава, а также использования автотранспорта для осуществления патрулирования.

3. Разработка и принятие плана, обеспечивающего использование сил и средств полиции.

4. УПравленческая деятельность нарядами ППСП.

Схожую систему осуществления ООП и ООБ Российская Федерация имеет с Германией. Здесь основным подразделением, обеспечивающим ООП и ООБ на определенном территориальном участке, является "пункт охраны порядка», осуществляющий свою деятельность круглосуточно. С 1963 г. начала осуществление своих полномочий немецкая добровольная полицейская служба. Сотрудники, осуществляющие свою деятельность в данном подразделении, обязаны были пройти специализированную подготовку, после чего были наделены правом нести службу на постах численностью от 10 до 15 человек. Сотрудники, осуществляющие службу в указанном подразделении, привлекались в основном в целях осуществления охраны порядка при массовых мероприятиях, в качестве усиления регулярных полицейских формирований, а также для поиска пропавших без вести.

Таким образом, общественный порядок и общественная безопасность - взаимообусловленные, но не тождественные понятия. Общественный порядок является более широким понятием. В связи с этим первое создает условия для осуществления второго. 
Резюмируя вышеизложенное представляется целесообразным сформулировать следующие предложения, направленные на повышение уровня ООП и ООБ в деятельности полиции:

1. Комплексное совершенствование действующей нормативной правовой основы, регламентирующей ООБ и ООП полицией.

2. Детализация целей и задач полиции, а также полномочий в рамках ООБ и ООП.

3. Исполнение целевых программ, а также внесение предложений по их разработке и проведению.

4. Постоянное совершенствование механизма ООП и ООБ с учетом складывающейся обстановки в Российской Федерации.

Вышеуказанные меры, на наш взгляд, сформируют основу для построения и реализации оптимального уровня системы функций и задач полиции в сфере ООП и ООБ, а также предупреждения правонарушений и повышения общественной безопасности.

Воронежский институт МВД России

Занина Т. М., кандидат юридических наук, профбессор кафбедры административной деятельности органов внутренних дел

E-mail: agarckova.natali2016@yandex.ru

Центральный фбилиал Российского государственного университета правоcyдur

Федотова О. А., кандидат юридических наук, доцент кафбедры теории и истории права и государства

E-mail: agarckova.natali2016@yandex.ru
Voronezh Institute of the Russian Ministry of Internal Affairs

Zanina T. M., Candidate of Legal Sciences, Professor of the Administrative Activity of Internal Affairs Bodies Department

E-mail: agarckova.natali2016@yandex.ru

Central Branch of the Russian State University of Justice

Fedotova O. A., Candidate of Legal Sciences, Associate Professor of the Theory and History of Law and State Department

E-mail: agarckova.natali2016@yandex.ru 